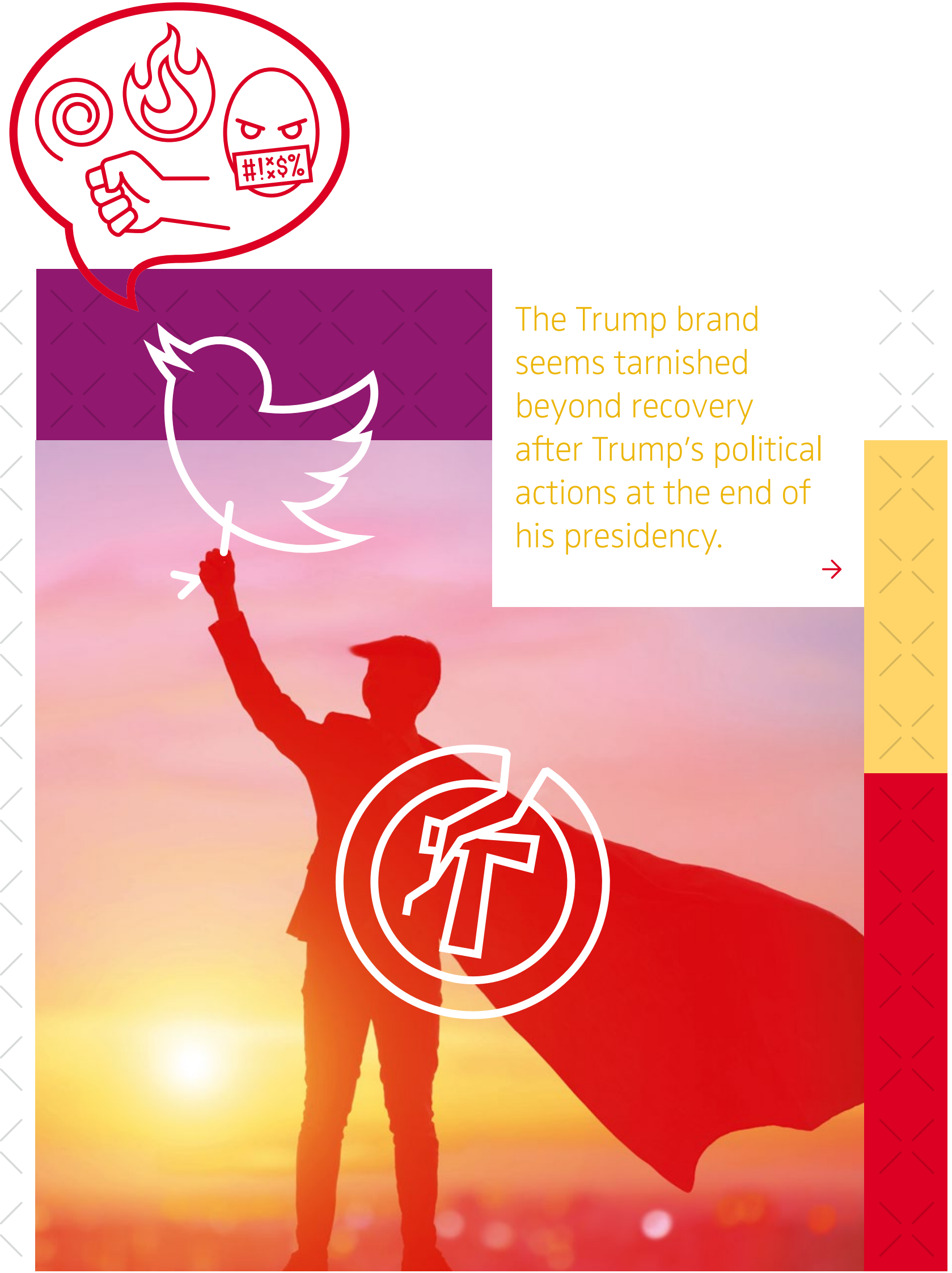




\title{
Tweeter-in-Chief Donald J. Trump: How Social Media Can Be the Downfall of Your Brand
}

\author{
Ron Hill, Sanal Mazvancheryl and Ben Wright
}

KEYWORDS

\section{Twitter, Political Marketing, Brand Management, Brand Value, Human Brands}

THE AUTHORS

\section{Ron Hill}

Professor of Marketing and Public Policy

ronhill@american.edu

\section{Sanal Mazvancheryl}

Assistant Professor of Marketing

sanal@american.edu

\section{Ben Wright}

Lecturer Marketing

bwright@american.edu

All: Kogod School of Business, The American University, Washington DC, USA
Capitol riots: The good, the bad, and the ugly $\times$ January 6 , 2021, will be remembered by American citizens as an important historical footnote among other tragedies, such as the 9/11 attacks and assassination of President John Fitzgerald Kennedy. Watching recent footage shown around the world can elicit panic, anger, frustration, and even joy. Yet, regardless of one's reactions, this event should not have come as a surprise. President Trump had been using social media, and predominantly Twitter, as a megaphone to magnify perceived accomplishments, to denigrate perceived enemies, and to call-to-arms his base of loyal followers. By the time this event unfolded, tech giants had occasionally slapped him on the wrist for lying to and inciting action by his admirers. However, insurrection was too much for them, leading to suspensions and his removal from most social media. This situation and its aftereffects will reverberate across societies, impacting politics and business in myriad ways.

The story behind Trump's tweets over time $\ltimes$ As a consequence, Trump was impeached, with the distinction of becoming the only president to have this designation twice, with only two others having been impeached once in the U.S. Detractors have provided evidence of his misdeeds by looking at various tweets and their content over time. However, this process of reviewing his postings can get bogged down in specific messages or ideas, rather than recognizing the larger content and its focus. Somewhat like missing the forest for the trees. It is true that Trump typically reserved praise for himself or those who praised him, and he used negative and often personal remarks to characterize most others. Further, his tweets moved from a more balanced set of positive vs. negative postings to increasingly negative 
Figure 1 > Donald Trump's hero's journey through the lens of Campbell's monomyth

\begin{tabular}{|c|c|}
\hline Heroe's Departure & $\begin{array}{l}\text { Trump is master in his "old" corporate world - } \\
\text { a business genius of unparalleled success. } \\
\text { "I've got the hottest brand in the world." }\end{array}$ \\
\hline $\begin{array}{l}\text { Call by the } \\
\text { "Downtrodden" }\end{array}$ & $\begin{array}{l}\text { The US citizens call him to restore order and } \\
\text { vanquish enemies. } \\
\text { "Make America great again." }\end{array}$ \\
\hline Heroe's Initiation & $\begin{array}{l}\text { Trump enters another world and engages with } \\
\text { enemies that seek to keep him from his destiny. }\end{array}$ \\
\hline Belly of the whale & $\begin{array}{l}\text { Congress with democrats demonized as } \\
\text { "losers", "clueless", "crooked" and "radical". } \\
\text { "Fake News Media". }\end{array}$ \\
\hline Road of Trials & $\begin{array}{l}\text { The Russia ("Hoax") Investigation and } \\
\text { the Mueller Report, followed by the first } \\
\text { impeachment proceedings. }\end{array}$ \\
\hline Ordeal and first victory & $\begin{array}{l}\text { Trials seek to drain him of his sustaining energy, } \\
\text { but it is regularly renewed at rallies with } \\
\text { diehard supporters. Trump emerges victoriously } \\
\text { without being convicted, and cleansed of any } \\
\text { stain "no obstruction, no collusion". }\end{array}$ \\
\hline Return to previous life & End of Presidency. \\
\hline $\begin{array}{l}\text { Reluctance to leave and } \\
\text { refusal to return to the } \\
\text { old world }\end{array}$ & $\begin{array}{l}\text { "I won the election by a lot!" Storming of the } \\
\text { Capitol by supporters. }\end{array}$ \\
\hline $\begin{array}{l}\text { The hero returns but fails } \\
\text { to become master of two } \\
\text { worlds }\end{array}$ & $\begin{array}{l}\text { Moving out of the white house and settling } \\
\text { in Florida. }\end{array}$ \\
\hline
\end{tabular}




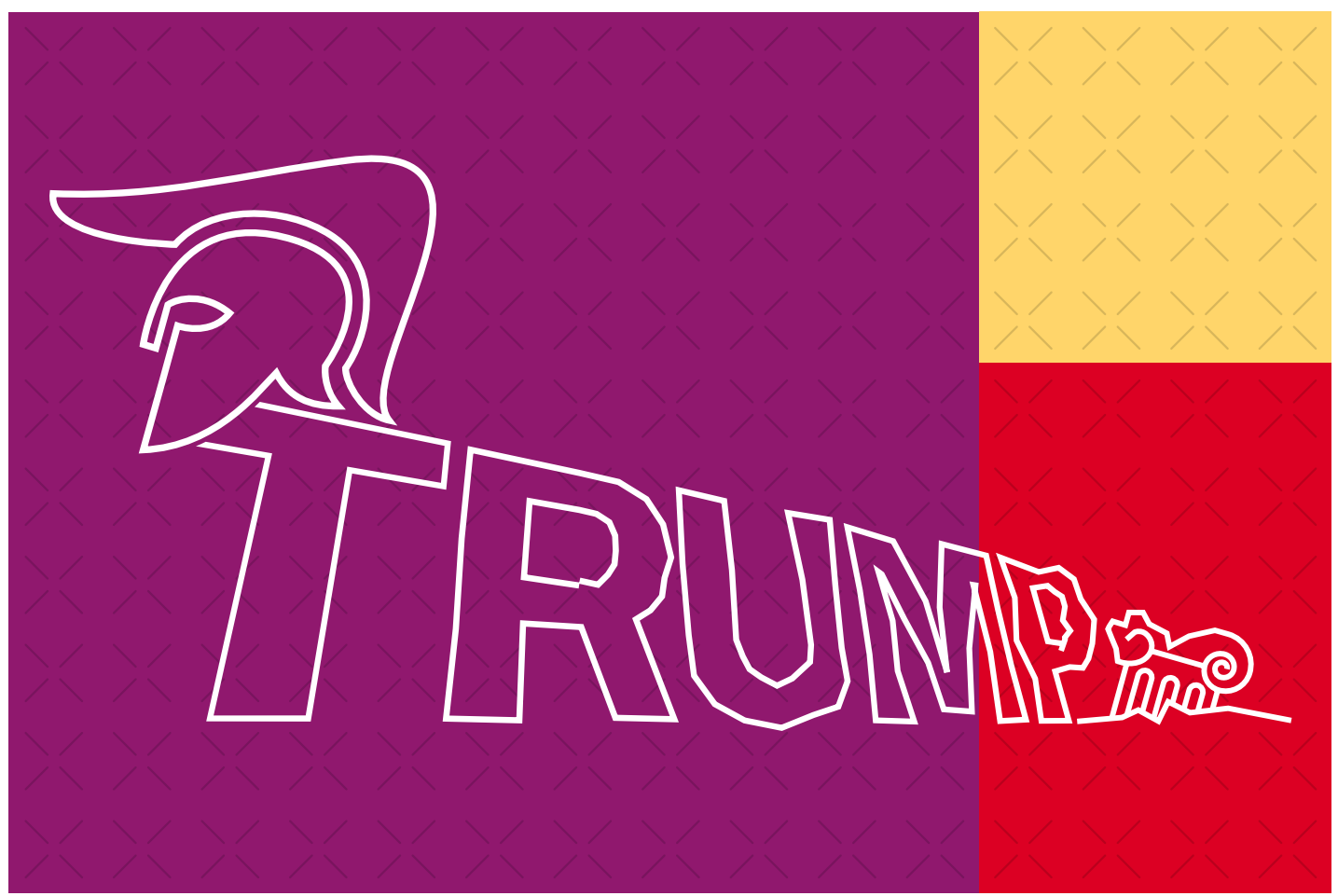

comments and rebellious action steps for his base. Nonetheless, our research team found a way to understand the totality of his 50,000 posts to his Twitter account using the myth of the hero's journey by the American Professor of Literature and Mythology, Joseph Campbell. In his work, he describes universal templates and phases found in any stories about adventures and heroics - the monomyth in the background. Trump's rise and fall is chronicled next within Campbells framework, followed by the story's impact on the Trump brand as a business entity.

Donald Trump as hero of his own story $`$ Trump has never shied away from media attention, and becoming president only exacerbated his need for its notice. His frustration with mainstream "fake news" media and probing questions by reporters led him to focus his communications with all constituencies on social media, referring to himself as a "Twitter wunderkind," despite his advancing age ("I'm the Ernest Hemingway of 140 characters"). Our research shows how each of the major stages of the hero's journey reinforced this status. Figure 1 depicts the stages of Trump's hero journey and illustrates the individual stages with typical Tweets or other Trump statements. The first stage is departure, as the hero/Trump moves from the familiar world of business into the unfamiliar world of politics. He is called to this adventure by "the downtrodden" to return America to former prominence and "Make America Great Again." A task that requires his supernatural powers which he and only he is able to accomplish.

The hero/Trump moves to initiation and engages with enemies that seek to keep him from his destiny. This stage has two interrelated facets that capture what occurred during his administration, titled "the road of trials" and the "belly of the whale." In this phase he removes obstacles, beats enemies, and fights villains. These trials seek to drain him of his sustaining energy, but it is regularly renewed at rallies with diehard supporters and he continues fulfilling his avocation.

The final stage is return to his previous life, as his time as president comes to an end. Depending upon the circumstances, the hero/Trump is reluctant to leave because the job of saving the citizenry is incomplete. There is only one viable path: Keeping a foot in politics and rising to the level of elder statesman, while regaining his position as a billionaire businessperson. Unfortunately for the latter, his refusal to return or become a master of both domains has resulted in propagation of unfounded claims of widespread voter 


\section{$\gg$ If the Trump brand does resurrect itself, it will be buoyed by a different target market.}

«

fraud, before and after the election. His list of perceived adversaries moved from "radical left" democrats to include republicans in congress and state houses who failed to overturn the election. As noted, the storming of the Capitol by supporters from his January 6th event, which coincided with the Electoral College vote count by the U.S. Congress, downgraded or eliminated his hero aura for all but his most ardent aficionados.

\section{Business backlash and destruction of the Trump brand $x$}

$>$ The Glorious days of the Trump brand $`$ Long before Trump made a hard right turn into politics, and before he was a TV reality star on "The Apprentice," the Trump brand was one of the strongest, even if controversial, human brands in the U.S. Through a combination of bravado, outrageous quotes, clown-like behavior, and bombastic claims rarely backed by facts, all of which were lapped up by ratings-seeking media, Trump managed to build a brand that sold the idea of luxury, exclusivity, and opulence to an affluent target clientele - a very different group than the "Trump Base" he came to embrace in political life. In addition to core businesses of real estate, golf clubs, and casinos, this reputation enabled Trump to extend or license his brand in such unrelated categories as steaks, airlines, dress shirts, vodka, and a highly questionable "University." His daughter Ivanka got into the act with a brand extension of clothing and accessories lines. While most of these brand extensions failed, followed by a series of bankruptcies, there were some notable exceptions. At its height, attaching the Trump brand to a property (which Trump rarely owned) would add up to $20 \%$ over the price compared to similar properties. In fact, reports indicate Trump (illegally) inflated his net worth to $\$ 8.7$ billion in 2013 , claiming $\$ 4.1$ billion in "brand value."

$>$ The decline of the brand begins $\ltimes$ Trump declared his candidacy for President in 2015 and was soon mired in controversy over his past behavior with and comments about women - even before the release of the "Access
Hollywood" tapes. He predictably followed it up with racist and anti-immigrant rhetoric and tweets, and the Trump brand's inevitable decline began. Corporations started cutting ties with the brand almost immediately. For example, NBC cut off ties with Trump, and Nordstrom stopped carrying Ivanka's clothing line in 2015-16. While it would have been difficult for any brand to occupy political space and consumer space simultaneously, it was clear that such efforts were backfiring for a brand whose primary spokesman was identified with incendiary rhetoric, polarizing social media comments like, "There were fine people on both sides" following the Charlottesville rally and protests, and controversial and draconian policies. An analysis by the Associated Press found that, by 2018, Trump branded properties and products were selling at up to a $20 \%$ discount relative to the market. After his impeachment in 2019, the election loss, and his unprecedented refusal to accept results of a fair U.S. election, the brand lost more ground in most product categories tracked by Brand Keys.

$>$ The ultimate crash $\times$ All of these issues pale in comparison to the backlash for the brand following the January 6th insurrection and attack by Trump supporters on the U.S. Capitol, which was followed by a second impeachment. What is believed to have upset Trump the most is the loss of the PGA golf tournament from his New Jersey golf club in 2022, as the PGA of America Board of Directors exercised the right to terminate the agreement shortly after the January 6th event. The PGA, which has an over 100 year history in the game of golf, also released a strong statement, indicating that "Conducting the PGA Championship, one of four major U.S. golf tournaments, at Trump Bedminster would be detrimental to the PGA of America Brand." Further, his lender of last resort, Deutsche Bank and others announced that they would no longer welcome Trump's business. New York City has also decided to cut all ties with his businesses. While some personal brands like Martha Stewart have recovered from mini-scandals, a turn for the Trump brand seems unlikely. 


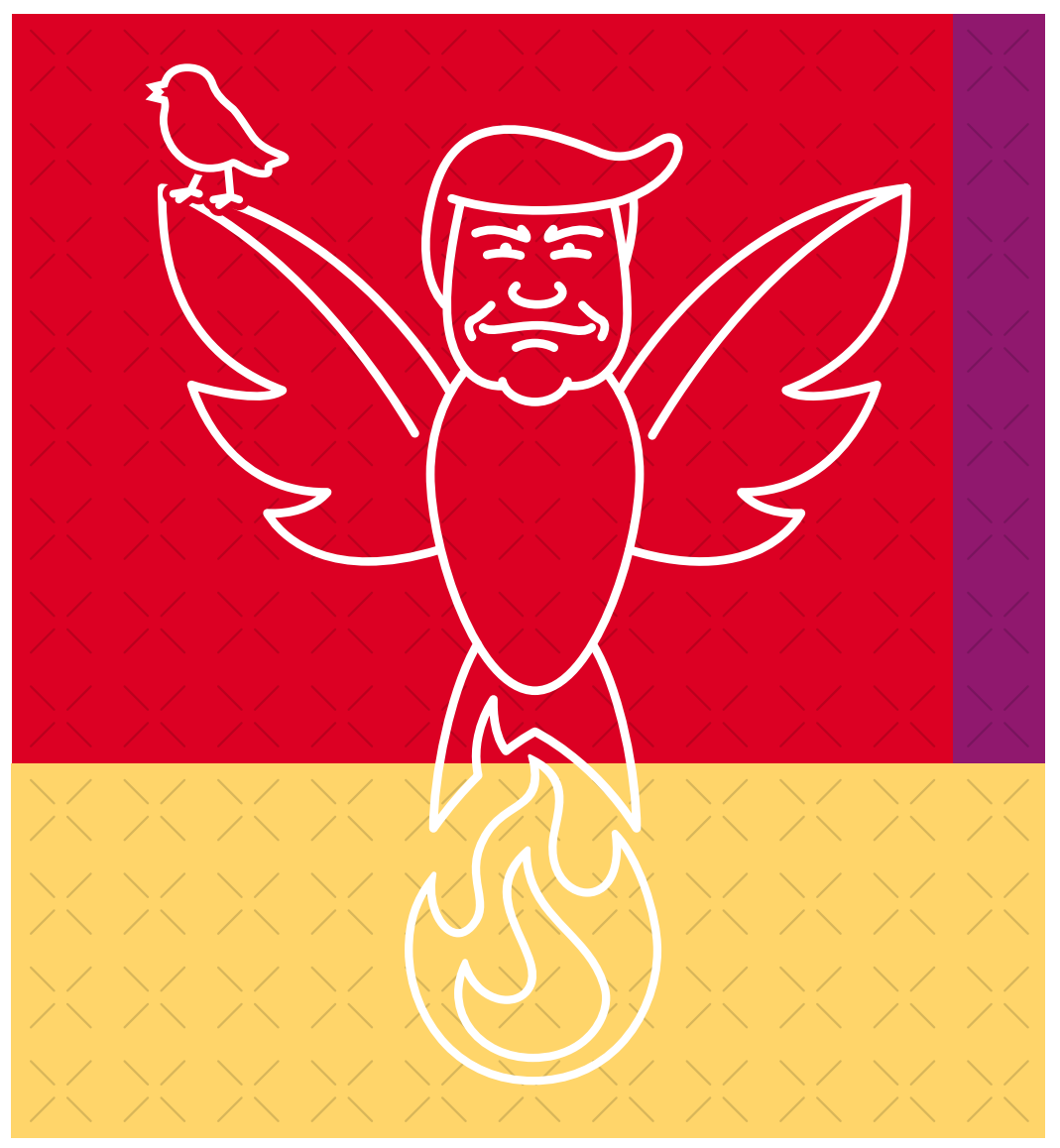

Will the hero be able to return? $\times$ While many hero's journeys in mythology and Hollywood have happy endings, with the hero returning triumphantly and changed to the realm of his departure, the "greatest President ever" failed politically and with his brands in business matters - at least for now. Even as the second impeachment failed again with a frighteningly high number of Republicans refusing to vote for impeaching the former president, Trumps reemergence in the world of politics still seems unlikely, at this point. Given the magnitude of the issues leading to Trump's fall and the several legal issues he is facing, the Trump brand seems tarnished beyond recovery for the foreseeable future. If it does resurrect itself, it will be buoyed by a different target market that is made up of primarily White Americans who are disgruntled with their lots in life, seeking to find someone else to blame. Can he survive financially selling MAGA hats and shirts as well as taking donations based on the premise of his rise to power once again? Only time will tell.

Campbell, J (1968): "The Hero with a Thousand Faces", NJ: Princeton University Press.

Hill, R., Wright, B., and Bennett, A. (2021):

"Storytelling and the Hero's Journey: The Trump Brand and Social Media," working paper.

https://hbr.org/2020/02/how-do-consumers-feelwhen-companies-get-political

https://www.nytimes.com/2021/01/11/business/ trump-brand-capitol-mob.html 